\title{
KOMUNIKACIJA
}

\section{POLITINIŲ PARTIJŲ DALYVAVIMAS KOALICINĖSE VYRIAUSYBĖSE: ATSPINDŽIAI NACIONALINĖJE LIETUVOS ŽINIASKLAIDOJE (1996-2013)'}

Prof. DR. Irmina Matonyté

Lietuvos socialiniu tyrimu centras Lithuanian social research centre A. Goštauto g. 11, LT-01108 Vilnius

El.paštas matonyte@ktl.mii.lt

Dr. Vincentas Vobolevičius

ISM Vadybos ir ekonomikos universitetas

ISM University of Management and Economics

Arkliu g. 18, LT-01129 Vilnius

El.paštasvinvob@ism.lt

\section{Santrauka}

Politologijoje postuluojamas reikšmingas politiniu partiju vaidmuo koalicinèse vyriausybèse, todèl tikètina, kad šalies žiniasklaidoje, aprašančioje koaliciniu vyriausybiu veikla, politinèms partijoms bus skiriamas didelis demesys. Šiame straipsnyje tarpdisciplininio tyrimo büdu, gretinant lyginamosios politikos ir žiniasklaidos studiju metodus, siekiama išsiaiškinti, ar politinès partijos, kaip svarbūs koalicines vyriausybès ir koalicinès valdysenos aktoriai, išryškejja Lietuvos žiniasklaidoje. Pirmiausia straipsnyje pateikiama Lietuvos

1 Už pagalbą analizuojant žiniasklaidos archyvą ir rengiant straipsnị autoriai dèkoja studentei Augustinai Zamuškevičiūtei (ISM Vadybos ir ekonomikos universitetas). 
žiniasklaidos stebèsenos apžvalga, analizuoty dienraščiu ir interneto portaly populiarumo tendencijos bei analizès metodologija. Toliau aptariama politiniu partiju reikšmé Lietuvos koalicinès valdysenos kontekste, akcentuojami reikšmingi partiniai koaliciniu vyriausybiu formavimo, veiklos ir atsistatydinimo aspektai. Atsižvelgiant $i$ koalicijų teorijos jžvalgas, keliamos hipotezès apie žiniasklaidos straipsniu, kuriuose aprašomi skirtingi Lietuvos koaliciniu vyriausybiu tipai ir ju veikla, tikètina demesi partijoms bei šio dèmesio dinamiką. Empirinis tyrimas remiasi rašytinès žiniasklaidos stebèsenos duomenimis, apimančiais visuomenès informavimo priemoniu perteikta informacija, susijusia su koaliciniu vyriausybiu darbu Lietuvoje 1996-2013 metais. Tyrimo rezultatai rodo, kad apžvalginiai žiniasklaidos straipsniai, aprašę ir komentavę Lietuvos koaliciniu vyriausybiu veikla, kaip ir politologiškai tiketasi, partijoms santykinai daugiau dèmesio skyrè mažumos vyriausybiu atveju, o straipsniuose, pristatančiuose minimalios persvaros ir pertekliniu koaliciju. darba, partijos figūravo mažiau. Vis dèlto, kitaip negu suponuoja politologine jžvalga, pasirodè, kad Lietuvos viešojoje erdveje partiju, kaip kolektyvinio veikèjo, reikšmè svarbiausia buvo koaliciju valdymo, o ne formavimo etape. Chronologines straipsniu analizés büdu buvo atmesta ir hipotezé, kad laikui bégant politikai ir žurnalistai mokosi ir vis plačiau atskleidžia reikšminga partiju vaidmeni koalicinèse vyriausybèse. Taip pat svarbu akcentuoti, kad Lietuvos žiniasklaidoje straipsniu antraštèse partiniu aspektu yra reikšmingai mažiau negu straipsniu tekstuose.

Reikšminiai žodžiai: Lietuva; koalicinė vyriausybė; partija; Ministras Pirmininkas; nacionalinis dienraštis; informacinis portalas; antraštė; tekstas. 


\section{Itvadas}

Klasikinès politologijos teorijos ir vyriausybių, veikiančių demokratinèse santvarkose, studijos ${ }^{2}$ politines partijas laiko kertiniu vykdomosios valdžios elementu. Politinès partijos atspindi ideologines takoskyras, skirtingus elektoratus ir lyderius pritraukiančių ir vienijančių organizacinių vienetų skirtumus, politinių-socialinių konfliktų intensyvumą ir formas. Partijos, kaip kolektyviniai aktoriai, deleguoja savo atstovus $\mathfrak{i}$ valdžią, juos daugiau ar mažiau veiksmingai kontroliuoja ir didesne ar mažesne apimtimi yra atsakingos už savo atstovų, užimančių postus valdžioje, sprendimus. Politinių partijų vaidmuo ypač didelis koalicinèse vyriausybėse, kurios sudaromos ir veikia pagal keleto atskirų partijų susitarimą. Nors politologijoje vienos partijos suformuotų vyriausybių veiklą supaprastintai kartais ir dera tapatinti su vyriausybès vadovo (premjero, Ministro Pirmininko, kanclerio) asmeniu, tai daryti koalicinių vyriausybių atveju neįmanoma, nes skirtingų partijų svarba ir vaidmuo koalicinèse vyriausybèse gerokai išauga ${ }^{3}$. Atitinkamai galima suponuoti, kad šalies žiniasklaidoje, aprašančioje koalicinių vyriausybių veiklą, politinėms partijoms yra skiriamas didelis dèmesys, ir informaciniai pranešimai bei politikos komentatorių ¡žvalgos, susiję su vyriausybę sudarančių partijų veikla, yra esminis atitinkamų žiniasklaidos pranešimų struktūros ir turinio veiksnys ${ }^{4}$. Empiriškai patikrinti, kaip (ar) veikia šios akademinès prielaidos apie pilietinès žiniasklaidos dėmesí politinèms partijoms koalicinėse vyriausybèse, galima analizuojant ir gretinant dvejopus suvestinius duomenis: informaciją apie šalies koalicinių vyriausybių partinę sudètị

2 Gallagher, M., Laver, M., Mair, P. Representative government in modern Europe. $3^{\text {rd }}$ ed. Boston: McGraw Hill, 2001, p. 340.

3 Coalition governments in Western Europe. Edited by W.C. Muller, K. Strom. New York: Oxford University Press Inc., 2006, p. 2, 560.

4 Cabinets and coalition bargaining: the democractic life cycle in Western Europe. Edited by K. Strøm, W.C. Müller, T. Bergman. Oxford: University Press, 2008, p. 53-55. 
ir atitinkamų žiniasklaidos pranešimų turinị ir randamus „partinius“ akcentus. Pirmojo tipo duomenys yra politiniai struktūriniai-instituciniai koalicinių vyriausybių rodikliai. O antrojo tipo duomenų bazę sudaro atitinkamo žiniasklaidos turinio stebėsenos medžiaga. Informacija, sukaupta atlikus žiniasklaidos stebėseną, leidžia naudojant turinio analizès metodą gilintis ị piliečiams pateikiamos informacijos kokybę, žiniasklaidos straipsniuose skelbiamų naujienų adekvatumą, išsamumą, įvairovę. Tokia žiniasklaidos stebėsena galima pamatuoti, kokia apimtimi ir kaip žiniasklaida atlieka pilietinio forumo ${ }^{5}$ funkciją.

Straipsnyje pristatomas Lietuvos koalicinių vyriausybių ir jas sudarančių politinių partijų atspindžių nacionalinèje žiniasklaidoje tyrimas. Tokio pobūdžio tarpdisciplininis tyrimas, kuriame persipintų lyginamosios politikos ir žiniasklaidos studijų metodai ir interesai, yra gana novatoriškas tiek Vakarų akademijos kontekste, tiek ir Lietuvos socialinių mokslų tradicijoje. Lietuvoje įvairiais koalicinių vyriausybių aspektais yra rašyta politologų Irminos Matonytės ir Gretos Gerazimaitès ${ }^{6}$ (apie koalicinių vyriausybių susitarimų ir sutarčių turinị bei specifiką), Alvido Lukošaičio (besigilinančio ị Lietuvos vyriausybės ir prezidento santykius ${ }^{7}$ ir analizuojančio koalicinės mažumos vyriausybès (2006 m. birželio mèn. - $2008 \mathrm{~m}$. spalio mėn.) atsiradimą, veiklos aplinkybes ir problemas ${ }^{8}$ ), Vitalio Nakrošio ${ }^{9}$ (tiriančio ministerinès

Norris, P.A. Virtuous circle: political communications in postindustrial societies. Cambridge: Cambridge University Press, 2000.

6 Matonytė, I., Gerazimaitè, G. Koalicinių vyriausybių morfologija: akademiniai postulatai, Vakarų Europos patirtys ir atvejai Lietuvoje. Parlamento studijos. Nr. 14 (2013), p. 11-39.

7 Lukošaitis, A. Parlamentas ir parlamentarizmas. Krupavičius, A., Lukošaitis, A. Lietuvos politiné sistema: sąranga ir raida. Vilnius: Poligrafija ir informatika, 2004, p. 343-384.

8 Lukošaitis, A. Koalicinė mažumos vyriausybė Lietuvoje: sudarymo aplinkybės ir veiklos problemos. Lietuvos metiné strategine apžvalga, 2007. Vilnius: LKA, 2008, p. 241-296.

9 Nakrošis, V. Viešoji administracija. Krupavičius, A., Lukošaitis, A. Lietuvos politiné sistema: sąranga ir raida. Vilnius: Poligrafija ir informatika, 2004, p. 422-454. 
atsakomybès ir administracinès atskaitomybès praktikas pokomunistinejje Lietuvoje), Terry D. Clarko ir Dianos Jurgelevičiūtès ${ }^{10}$ (aptariančių, kaip Lietuvos daugiapartinèje sistemoje institucionalizuojamas politinių partijų, kartu sudarančių vyriausybes, tarpusavio nepasitikèjimas ir savo partnerių ịtarinejjimas). Reikšmingiausi straipsniai apie valdžios (vyriausybės) darbą ir politinę komunikaciją Lietuvos mokslinèje erdveje koncentruojasi ì politikos lyderių retorikos specifiką (Lauras Bielinis ${ }^{11}$ ), politinio humoro reikšmę (Jūratė Kavaliauskaité丶 ${ }^{12}$ ), polinki $\mathfrak{i}$ skandalingos ir neigiamos informacijos platinimą (Ingrida Unikaitè $^{13}$ ) ir pan.

Straipsnyje Lietuvos rašytinès žiniasklaidos stebėsenos duomenų ir ižvalgų analize siekiama atskleisti, kokios tendencijos būdingos apžvalginių žiniasklaidos straipsnių turiniui, atspindinčiam partijų vietą ir reikšmę Lietuvos koalicinèse vyriausybèse. Pirmiausia pristatoma Lietuvos žiniasklaidos stebėsena ir per politinių partijų prizmę aptariama koalicinių vyriausybių sudetis ir kaita. Tada, remiantis žiniasklaidos stebėsenos rezultatais, aprašomosios koalicinių vyriausybių apžvalgos fone, naudojant aprašomąją statistiką, tikrinamos iškeltos hipotezès. Vèliau, pasitelkiant kokybinę žiniasklaidos (turinio) medžiagą, interpretuojami gauti rezultatai, daromos išvados ir pateikiami apibendrinimai.

Abu tyrime naudojamų Lietuvos duomenų srautai (politiniai rodikliai ir žiniasklaidos stebėsenos duomenys) yra sukaupti 2011-2014 m. atliekant tarptautinị lyginamąji mokslinio tyrimo projektą „Vyriausy-

${ }^{10}$ Clark, T.D., Jurgelevičiūtè, D. "Keeping tabs" on coalition partners: a theoretically salient case study of Lithuanian coalitional governments. Europe-Asia Studies. Vol. 60, iss. 4 (2008), p. 631-642.

${ }^{11}$ Bielinis, L. Lingvistiniai politinès komunikacijos supratimo aspektai. Respectus Philologicus. 2002, Nr. 2, p. 49-59.

${ }^{12}$ Kavaliauskaite, J. Hybrid entertainment television: viewership of the Lithuanian "Dviracio Sou". Permitted laughter: socialist, post-socialist and never-socialist humour. Tartu: ELM Scholarly Press, 2009, p. 99-124.

${ }^{13}$ Unikaite, I. Negatyvumas Lietuvos Prezidento rinkimų kampanijose: mobilizuoja ar demobilizuoja rinkèjus? Politologija. 2008, Nr. 1, p. 121-145. 
bès Europoje“, kuris vienija dešimtị mokslininkų grupių iš Vidurio ir Rytų Europos šalių: Bulgarijos, Čekijos, Estijos, Latvijos, Lenkijos, Lietuvos, Rumunijos, Slovakijos, Slovėnijos ir Vengrijos. Šią akademinę Vidurio ir Rytų Europos studiją kuruoja trys universitetai: Vienos universitetas (Austrija), Siodertorno universitetas (Švedija), Korvino universitetas (Vengrija). Lietuvos koalicinès valdysenos (1996-2014) analizès turinį sudaro gausi empirinių duomenų bazė: koalicinių vyriausybių sutartys, penkiolika pusiau struktūruotų interviu su politinių partijų ir buvusių vyriausybių atstovais, apžvalginių Lietuvos nacionalinès žiniasklaidos straipsnių apie vyriausybių darbą archyvas, taip pat politikų memuarai ir komentarai. Straipsnio pagrindą sudaro žiniasklaidos archyvo duomenys.

\section{Lietuvos žiniasklaidos stebèsenos apžvalga}

Žiniasklaidos tekstų archyvas buvo sukauptas kaip antrinė medžiaga (pirminę medžiagą sudaro struktūriniai-instituciniai koalicinių vyriausybių rodikliai), apibūdinanti koalicinių vyriausybių veiklą Lietuvoje 1996-2013 metais. Taigi buvo atlikta kokybinė straipsnių atranka, per kurią sukaupta visuomenès informavimo priemonių (šiuo atveju spaudos ir interneto portalų) pateikta žurnalistinè, autorinė informacija, susijusi su koalicine valdysena. Tai nebuvo „masine“ stebėsena, kuri suarchyvuotų visas, net pačias trumpiausias ir skandalingiausias žinutes apie koalicines vyriausybes. Šioje kokybineje straipsnių atrankoje buvo naudojami šie paieškos (reikšminiai) žodžiai: koalicija, koalicijos formavimas, vyriausybè, vyriausybès formavimas, koalicinés vyriausybès derybos, koalicinis susitarimas, koalicine sutartis, interpeliacija, nepasitikejimas vyriausybe, nepasitikejimas koalicija ir koalicijos / vyriausybès krizè. Svarbu akcentuoti, kad, vengiant ekstensyvaus straipsnių archyvavimo, buvo siekiama atrinkti reikšmingiausius iš jų, kurie nekartotų tos pačios naujienos (žinutès) ir pateiktų žurnalistinius komentarus ir interpretacijas ( $\mathfrak{i}$ archyvą nebuvo ịtraukti interviu su politikais). Ypa- 
tingas dèmesys žiniasklaidos stebėsenoje buvo skirtas apžvalginiams straipsniams, kuriuose pateikiama „operatyvinè informacija“, susijusi su vienos ar kitos vyriausybės veikla. Apytiksliai santykis tarp surinktų informacinių straipsnių ir išplèstinių analitinių komentarų yra trys su vienu (3:1). Reikia akcentuoti, kad šioje stebèsenoje sąmoningai buvo orientuojamasi i dienraščius, o ne i savaitraščius, kurie dažniau publikuoja išsamius analitinius straipsnius (skirtus politiškai sąmoningiausiai ir raštingiausiai visuomenès daliai).

Šiame darbe naudojamą apžvalginių straipsnių visatekstị archyvą sudaro 533 vienetai (žr. 1 lentelę). Archyvuojant kiekvienas straipsnis buvo priskirtas konkrečiam vyriausybès kabinetui. Pateikiama straipsnio data, šaltinis, pavadinimas ir, atsižvelgiant ị turinị, nurodoma, kuriam vyriausybès gyvavimo etapui (formavimo, valdymo ir skilimo / baigties) jis priklauso.

Iš viso i̇ žiniasklaidos stebėseną buvo įtraukti šeši žiniasklaidos kanalai - keturi dienraščiai ir du interneto naujienų portalai. Dienraščiai „Respublika“ ir „Lietuvos rytas“ buvo pasirinkti todèl, kad tiriamuoju laikotarpiu jie buvo populiarūs ir politikos ịvykius pateikè autorinėmis žurnalistinėmis publikacijomis. Jų vidutinè metinè auditorija Lietuvoje svyravo tarp 4-10 proc. („Respublika“) ir 9-24 proc. („Lietuvos rytas“) ${ }^{14}$. Dienraščiai „Lietuvos aidas“ ir "Lietuvos žinios“ turèjo mažesnę skaitytojų auditoriją (2002-2007 m. „Lietuvos žinios“ turejjo 2-6 proc. auditorijos ${ }^{15}$ ), bet jie svarbūs politinèje žiniasklaidoje dèl politinio kryptingumo ${ }^{16}$. Nuo $2006 \mathrm{~m}$. ì stebèseną ịtraukti du interneto žiniasklaidos portalai - Delfi.lt ir Lrytas.lt, kurių skaitomumas Lietuvoje palaipsniui dideja. Pastebima, kad Lietuvoje nuo 2006 m. ir

14 TNS LT (2009). Metinė žiniasklaidos tyrimų apžvalga 2008. Prieiga per internetą: http://www.tns.lt [žiūrèta 2013 m. spalio 4 d.].

15 TNS LT (2012). Žiniasklaidos tyrimų apžvalga 2012. Prieiga per internetą: http:// www.tns.lt/lt/top/paslaugos/ziniasklaidos-auditoriju-tyrimai/metine-ziniasklaidostyrimu-apzvalga [žiūrèta $2013 \mathrm{~m}$. spalio $4 \mathrm{~d}$.].

16 Jastramskis, D. Žiniasklaidos organizacijos nuosavybès struktūros ir žiniasklaidos priemonės naujienų šališkumo ryšys. Informacijos mokslai. T. 51 (2009), p. 140. 
ypač pastaruoju metu mažèja skaitančių laikraščius ir auga interneto naujienų šaltinių naudojimas ${ }^{17}$. Pavyzdžiui, $2013 \mathrm{~m}$. birželio mèn. Delfi.lt turejjo 990676 realius vartotojus ir buvo populiariausias ir skaitomiausias naujienų portalas Lietuvoje ${ }^{18}$, kuris iš kitų žiniasklaidos rūšių (ne televizijos) turi didžiausią traukos galią ${ }^{19}$. Interneto portalas Delfi. It jau ilgą laiką yra pirmoje vietoje tarp populiariausių portalų. Lrytas. lt yra mažiau populiarus, $2013 \mathrm{~m}$. birželio mėn. jis turèjo 670494 realius vartotojus ${ }^{20}$. Pastaraisiais metais portalas Lrytas.lt sustiprejo; jis yra glaudžiai susijęs su dienraščiu „Lietuvos rytas“ (dienraščio „Lietuvos rytas“ ir portalo Lrytas.lt straipsniai analizuoti lygiagrečiai, jų rezultatai nedubliuojami).

\section{1 lentelé. Žiniasklaidos stebėsenos apžvalga}

\begin{tabular}{|c|c|c|}
\hline Leidinio pavadinimas & Stebėti metai & $\begin{array}{c}\text { Analizuotu straipsniu } \\
\text { skaičius }\end{array}$ \\
\hline „Lietuvos aidas" & $1996-2001$ & 86 \\
\hline „Respublika" & $1996-2007$ & 140 \\
\hline „Lietuvos žinios" & $2005-2007$ & 62 \\
\hline "Lietuvos rytas" & $1998-2007$ & 52 \\
\hline Lrytas.lt & $2008-2013$ & 135 \\
\hline Delfi.lt & $2008-2013$ & 53 \\
\hline
\end{tabular}

${ }^{17}$ Nevinskaite, L. Mus vienija alus ir televizija: žiniasklaidos auditorijos (ne) fragmentacija $2012 \mathrm{~m}$. Seimo rinkimų kampanijos metu. Politologija. 2014, Nr. $1(73)$, p. 67-97.

${ }^{18}$ Gemius. „gemiusAudience“ pristato naujoves. 2013. Prieiga per internetą: http://gemius.It/lt/gemius_audience_results_It/lt [žiūrèta $2013 \mathrm{~m}$. spalio $4 \mathrm{~d}$.].

${ }^{19}$ Nevinskaite, L. Mus vienija alus ir televizija: žiniasklaidos auditorijos (ne) fragmentacija $2012 \mathrm{~m}$. Seimo rinkimų kampanijos metu. Politologija. 2014, Nr. 1(73), p. 67-97.

${ }^{20}$ Gemius. ,gemiusAudience“ pristato naujoves. 2013. Prieiga per internetą: http:// gemius.lt/lt/gemius_audience_results_lt/lt [žiūrèta $2013 \mathrm{~m}$. spalio 4 d.]. 
Politinių ideologijų ir vertybių požiūriu Lietuvos spauda nèra labai diferencijuota, nes taikosi $\mathfrak{i}$ kuo platesnę auditoriją ${ }^{21}$ ir / ar $\mathfrak{i}$ komercini pelną $^{22}$. Vis dèlto galima atpažinti (skirtingais laikotarpiais labiau ar mažiau išreikštą) dienraščio ar portalo politinị tendencingumą, paralelizmą ${ }^{23}$. Vieno iš populiariausių Lietuvos dienraščių skaitytojai dažnai renkasi ir kitą didelio populiarumo sulaukiantị dienraštị. Pavyzdžiui, 40 proc. „Lietuvos ryto“ skaitytojų taip pat skaito „Respubliką“, o 72 proc. „Respublikos“ skaitytojų taip pat bent kartą per savaitę skaito „Lietuvos rytą “24. Dar didesnis persipynimas pastebimas tarp interneto naujienų portalų: 55 proc. Delfi.lt skaitytojų apsilanko ir Lrytas.lt interneto svetaineje, o net 93 proc. Lrytas.lt skaitytojų bent kartą per savaitę skaito Delfi.lt straipsnius ${ }^{25}$.

Atliekant žiniasklaidos stebėseną išryškèjo, kad straipsniai apie koalicines vyriausybes ir su jomis susijusios naujienos dažnai buvo pateikiamos pirmame ar antrame dienraščio puslapiuose (taip išryškinant pranešimų svarbą). Interneto portaluose (Delfi.lt ir Lrytas.lt) reikšmingas indikatorius yra skaitytojų komentarų dažnis. Pastebèta, kad interneto portaluose publikuojami straipsniai, susiję su koalicinèmis vyriausybėmis, paprastai sulaukia mažiau skaitytojų dėmesio (ko-

${ }^{21}$ Matonytė, I., Novelskaitė, A., Butkuvienè, E. Moterys rinkimų kampanijoje: pozicijos partijose ir atspindžiai žiniasklaidoje. Politologija. 2007, Nr. 2, p. 106.

22 Jastramskis, D. Žiniasklaidos organizacijos nuosavybès struktūros ir žiniasklaidos priemonės naujienų šališkumo ryšys. Informacijos mokslai. T. 51 (2009), p. 140.

${ }^{23}$ Matonytė, I., Novelskaitė, A., Butkuvienè, E. Moterys rinkimų kampanijoje: pozicijos partijose ir atspindžiai žiniasklaidoje. Politologija. 2007, Nr. 2, p. 106; Jastramskis, D. Žiniasklaidos organizacijos nuosavybès struktūros ir žiniasklaidos priemonės naujienų šališkumo ryšys. Informacijos mokslai. T. 51 (2009), p. 140; Jastramskis, D. Lietuvos žiniasklaidos sistemos modelio bruožai. Informacijos mokslai. T. 55 (2011), p. 52-70; Balčytienè, A. Dependencies, parallelisms, and connections: Central and East European media as systems in flux. Media Transformations. Vol. 8 (2012), p. 48-69.

${ }^{24}$ Nevinskaitè, L. Mus vienija alus ir televizija: žiniasklaidos auditorijos (ne) fragmentacija 2012 m. Seimo rinkimų kampanijos metu. Politologija. 2014, Nr. 1(73), p. 67-97.

25 Ten pat. 
mentarų) negu tekstai apie pramogų pasaulį, tačiau tekstai apie vyriausybes tikrai dažnai skaitomi ir matomi, nes ị juos neretai ịterpiamos reklaminès žinutès. Pavyzdžiui, portale Lrytas.lt publikuotas straipsnis „Koalicijos pastumtas V. Ušackas krenta iš ministro kèdès“ sulaukè 262 komentarų, o kitas tą pačią Vyriausybę aprašantis straipsnis „Premjeras nemato problemų, kad ministrų komandos formuojamos partiniu principu“ - tik 21.

Toliau (1 paveikslas) pateikiamas „žodžių debesis“, padarytas naudojant http://tagcrowd.com tinklalapyje pateikiamą programą, kuri vizualizavo pagrindinius žodžius, 1996-2013 metais naudotus straipsnių apie koalicines vyriausybes antraštėse.

1 paveikslas. Svarbiausi žodžiai straipsnių apie koalicines Lietuvos vyriausybes antraštėse (1996-2013)

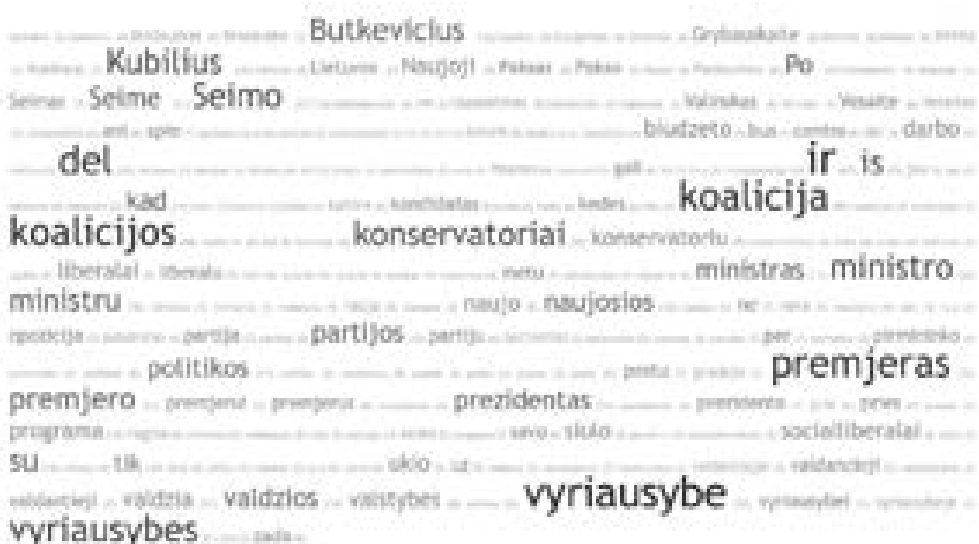




\section{Politinių partijų struktūrinès vietos Lietuvos koalicinèse vyriausybèse apžvalga}

Paprastai koalicinės vyriausybės skirstomos ị keturis tipus: a) mažumos vyriausybes, kurias sudarančioms partijoms priklauso 50 proc. ar mažiau parlamento (žemesniųjų parlamento rūmų) vietų; b) perteklines koalicijas, kai atsiskyrus kuriai nors vienai iš koalicijos partijų partnerių, likusi koalicija ir toliau turètų daugumą parlamente; c) minimalios persvaros koalicijas - kabinetus, kurie netektų parlamento daugumos po bet kurios partijos pasitraukimo; d) vienos partijos daugumos vyriausybes. Tiriamuoju laikotarpiu Lietuvoje nẻ kartą nebuvo suformuota plačioji (didžioji, vaivorykštès) koalicija, apimanti praktiškai visą parlamente atstovaujamą politinių ideologijų ir stovyklų spektrą. Tačiau iniciatyvų suformuoti plačią vaivorykštės koaliciją, nepaisančią partinių skirtumų, būta nemažai (ir jos dažniausiai kildavo iš Lietuvos Respublikos Prezidento institucijos). Vis dèlto Lietuvos politinëje praktikoje tiek sudarant vyriausybes, tiek jų veikloje, atrodo, yra reikšmingi partiniai interesai, programos, tapatybès ir panašūs dalykai, ir pilietinè ar kita dalykinė retorika neįveikia stebimos tendencijos formuoti pagal programas ar ideologiją panašių partijų koalicijas. Partinis veiksnys Lietuvos vyriausybėse struktūriniu instituciniu požiūriu yra faktiškai ir funkciškai neabejotinai svarbus.

Šiame tyrime Lietuvos koalicinès vyriausybès klasifikuotos ị minètus keturis tipus pagal tai, kiek mandatų Seime turejjo atitinkamą vyriausybę sudarančios partijos vyriausybès suformavimo dieną (o ne pagal tai, kokia balsų dauguma vyriausybė buvo paremta jos ịvesdinimo dieną ar kokią parlamentinę paramą už atskirus ịstatymus vyriausybė sugebėdavo pritraukti, mobilizuodama palaikymą iš kitų partijų, neturinčių postų toje vyriausybejje) (žr. 2 lentelę). Akcentuotina (2 lentelès stulpelis „Kabineto stiprumas vyriausybės atsistatydinimo išvakarèse“), kad daugelio kabinetų veiklos metu Lietuvoje koalicinès vyriausybès parlamentinè parama Seime keitėsi (mažèjo), nes Lietuvos parlamentiniam elitui bū- 


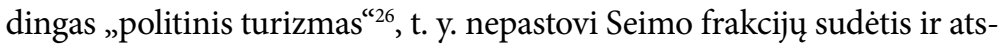
kirų parlamentarų judèjimas iš vienos partijos ị kitą. Vyriausybės darbo pabaiga šiame tyrime laikoma diena, kai a) vyriausybè (Ministras Pirmininkas) atstatydinama (atsistatydina); b) iš vyriausybès sudèties oficialiai išeina kuri nors ją sudariusi partija (pvz., Naujoji sąjunga (socialliberalai) išèjo iš Ministro Pirmininko Algirdo Mykolo Brazausko vadovaujamos Vyriausybès 2006 m. balandžio mèn., kai iš Seimo Pirmininko pareigų buvo atstatydintas šios partijos vadovas Artūras Paulauskas); c) vyksta eiliniai Seimo rinkimai (pirmasis turas).

2 lentelè. Koalicinės vyriausybės Lietuvoje: vyriausybės vadovas, valdymo laikotarpis, vyriausybès pobūdis, partinè sudètis ${ }^{\star}$

\begin{tabular}{|c|c|c|c|c|c|c|c|}
\hline $\begin{array}{l}\text { Minis- } \\
\text { tras } \\
\text { Pirmi- } \\
\text { ninkas }\end{array}$ & $\begin{array}{c}\text { Darbo } \\
\text { pradžia }\end{array}$ & $\begin{array}{c}\text { Darbo } \\
\text { pabaiga }\end{array}$ & $\begin{array}{c}\text { Vyriau- } \\
\text { sybės } \\
\text { tipas }\end{array}$ & $\begin{array}{c}\text { Kabi- } \\
\text { neto } \\
\text { partinè } \\
\text { sudètis }\end{array}$ & $\begin{array}{c}\text { Kabineto } \\
\text { stip- } \\
\text { rumas } \\
\text { vyriausy- } \\
\text { bės darbo } \\
\text { pradžioje } \\
\text { (daugiau- } \\
\text { sia 141) }\end{array}$ & $\begin{array}{c}\text { Kabineto } \\
\text { stip- } \\
\text { rumas } \\
\text { vyriau- } \\
\text { sybès } \\
\text { atsistaty- } \\
\text { dinimo } \\
\text { išvaka- } \\
\text { rèse } \\
\text { (daugiau- } \\
\text { sia 141) }\end{array}$ & $\begin{array}{c}\text { Efek- } \\
\text { tyvių } \\
\text { parla- } \\
\text { men- } \\
\text { tinių } \\
\text { partijų } \\
\text { skaičius } \\
\star * * * \star\end{array}$ \\
\hline $\begin{array}{l}\text { Vagno- } \\
\text { rius }\end{array}$ & $\begin{array}{c}1996-12- \\
10\end{array}$ & $\begin{array}{c}1999-05- \\
03\end{array}$ & $\begin{array}{c}\text { Pertekli- } \\
\text { né }\end{array}$ & $\begin{array}{c}\text { TS-LKD, } \\
\text { LKDP, } \\
\text { LCS }^{* *}\end{array}$ & 100 & 78 & 3,3 \\
\hline Paksas I & $\begin{array}{c}1999-06- \\
10\end{array}$ & $\begin{array}{c}1999-10- \\
27\end{array}$ & $\begin{array}{c}\text { Minima- } \\
\text { lios pers- } \\
\text { varos }\end{array}$ & $\begin{array}{c}\text { TS-LKD, } \\
\text { LKDP }\end{array}$ & 74 & 74 & 3,5 \\
\hline $\begin{array}{l}\text { Kubi- } \\
\text { lius I }\end{array}$ & $\begin{array}{c}1999-11- \\
11\end{array}$ & $\begin{array}{c}2000-10- \\
08\end{array}$ & \begin{tabular}{|c|} 
Minima- \\
lios pers- \\
varos
\end{tabular} & $\begin{array}{c}\text { TS-LKD, } \\
\text { LKDP }\end{array}$ & 74 & 61 & 3,5 \\
\hline
\end{tabular}

${ }^{26}$ Matonytė, I., Šumskas, G. Lithuanian parliamentary elites after 1990: dilemas of political repesentation and political professionalism. Edited by E. Semenova, M. Edinger, H. Best. Parliamentary elites in Central and Eastern Europe: recruitment and representation. New York, NY: Routledge, 2014, p. 145-168. 


\begin{tabular}{|c|c|c|c|c|c|c|c|}
\hline Paksas II & $\begin{array}{c}2000-11- \\
09\end{array}$ & $\begin{array}{c}\text { 2001-06- } \\
19\end{array}$ & $\begin{array}{c}\text { Mažu- } \\
\text { mos }\end{array}$ & $\begin{array}{c}\text { LLS, } \\
\text { LCS, } \\
\text { NS-SL, } \\
\text { MKDS }\end{array}$ & 66 & 66 & 6,1 \\
\hline $\begin{array}{c}\text { Brazaus- } \\
\text { kas I }\end{array}$ & $\begin{array}{c}\text { 2001-07- } \\
12\end{array}$ & \begin{tabular}{|c|}
$2004-10-$ \\
24
\end{tabular} & $\begin{array}{c}\text { Minima- } \\
\text { lios pers- } \\
\text { varos }\end{array}$ & $\begin{array}{l}\text { LSDP, } \\
\text { NS-SL }\end{array}$ & 74 & 73 & 6,6 \\
\hline $\begin{array}{c}\text { Brazaus- } \\
\text { kas II }\end{array}$ & $\begin{array}{c}2004-12- \\
14\end{array}$ & $\mid \begin{array}{c}2006-04- \\
11\end{array}$ & $\begin{array}{c}\text { Minima- } \\
\text { lios pers- } \\
\text { varos }\end{array}$ & $\begin{array}{c}\text { LSDP, } \\
\text { DP, } \\
\text { NS-SL, } \\
\text { VNDS }\end{array}$ & 80 & 80 & 6,2 \\
\hline $\begin{array}{c}\text { Bra- } \\
\text { zauskas } \\
\text { III }^{* * *}\end{array}$ & $\begin{array}{c}2006-05- \\
25\end{array}$ & \begin{tabular}{|c|}
$2006-06-$ \\
01
\end{tabular} & $\begin{array}{c}\text { Minima- } \\
\text { lios pers- } \\
\text { varos }\end{array}$ & $\begin{array}{l}\text { LSDP, } \\
\text { DP, } \\
\text { VNDS }\end{array}$ & 71 & 59 & 6,2 \\
\hline Kirkilas & $\begin{array}{c}2006-07- \\
18\end{array}$ & $\begin{array}{c}2008-10- \\
26\end{array}$ & $\begin{array}{c}\text { Mažu- } \\
\text { mos }\end{array}$ & $\begin{array}{c}\text { LSDP, } \\
\text { PDP, } \\
\text { LiCS, } \\
\text { VNDS }\end{array}$ & 59 & 73 & 7,6 \\
\hline $\begin{array}{c}\text { Kubilius } \\
\mathrm{II}^{* * * *}\end{array}$ & $\begin{array}{c}2008-12- \\
09\end{array}$ & $\begin{array}{c}2012-10- \\
28\end{array}$ & $\begin{array}{c}\text { Pertekli- } \\
\text { nè }\end{array}$ & $\begin{array}{c}\text { TS-LKD, } \\
\text { LiCS, } \\
\text { TPP, } \\
\text { LRLS }\end{array}$ & 80 & 64 & 5,6 \\
\hline $\begin{array}{c}\text { Butkevi- } \\
\text { čius }\end{array}$ & $\begin{array}{c}2012-12- \\
13\end{array}$ & - & $\begin{array}{c}\text { Pertekli- } \\
\text { nè }\end{array}$ & $\begin{array}{c}\text { LSDP, } \\
\text { DP, TT, } \\
\text { LLRA }\end{array}$ & 85 & $\mathrm{Nd}$ & 5,3 \\
\hline
\end{tabular}

* Partijų pavadinimai sukoduoti „retrospektyviai“, nesismulkinant ị faktinius atitinkamo laikotarpio oficialius partijų pavadinimus.

${ }^{* *}$ LCS nebuvo pasirašiusi koalicinès vyriausybès sutarties su tokią sutartị sudariusiomis TS-LKD ir LKDP, tačiau faktiškai LCS buvo vyriausybès ir parlamentinès daugumos dalis.

*** Brazauskas III vyriausybe išskirta kaip atskira vyriausybė, nes joje, palyginti su Brazauskas II vyriausybe, buvo pasikeitusi partijų sudètis.

**** Kubilius II vyriausybè nesuskaidyta ị dvi vyriausybes, nors jos valdymo laikotarpiu faktiškai keitèsi partine sudetis, t. y. TPP, kaip partijos, iš viso neliko. Tačiau jokiu momentu nebuvo atšaukti TPP deleguoti ministrai ir TPP pasirašyta koalicijos sutartis.

***** Efektyvių partijų rodikliai apskaičiuoti pagal atitinkamos vyriausybės sudarymo metu buvusị Seimo narių pasiskirstymą partijų frakcijose. Kubilius II ir Butkevičius vyriausybių atveju duomenys paimti iš M. Jurkyno apžvalgos ${ }^{27}$.

${ }^{27}$ Jurkynas, M. The parliamentary election in Lithuania, October 2012. Electoral Studies (2013). Prieiga per internetą: http://dx.doi.org/10.1016/j.electstud.2013.08.019. 
Formali vyriausybès igaliojimų suteikimo procedūra Lietuvoje parlamento balsavimas dèl naujai suformuotos vyriausybės, kartu pritariant ir formuojamos vyriausybès programai. Iš tikrųjų tai yra iš dviejų etapų susidedanti procedūra: pirmiausia, kaip nurodo Lietuvos Respublikos Konstitucija, Seimas balsuoja dèl Ministro Pirmininko kandidatūros, o po 15 dienų - dèl vyriausybès programos. Paprastosios daugumos principas yra taikomas šioje dviejų žingsnių vyriausybès formavimo procedūroje, t. y. kai Seimo posėdyje „už“ balsuojančių parlamentarų turi būti daugiau nei pasisakančių „prieš“ (ir susilaikančiųjų). Pirmame etape Ministro Pirmininko kandidatūrą teikia Lietuvos Respublikos Prezidentas. Seimo patvirtintas kandidatas ị Ministro Pirmininko postą ippareigojamas suformuoti naują kabinetą. Seimas, balsuodamas antrame etape, išreiškia palaikymą ne tik vyriausybès programai, bet ir vyriausybės kabinetui. Konstitucijoje ịtvirtintas 15 dienų laikotarpis naujai vyriausybei suformuoti neleidžia daug laiko skirti deryboms po rinkimų tarp partijų dèl valdančiosios koalicijos sudarymo.

Šiame tyrime naujos vyriausybės sudarymo data laikoma pirmoji antrojo etapo diena. Politinė pirmojo etapo svarba yra nenuginčijama, nes simbolizuoja igaliojimų vyriausybei formuoti suteikimą ir ipareigoja per dvi savaites sudaryti vyriausybès programą. Vienintelis atvejis istorijoje, kai Seimas nepatvirtino Prezidento teikto kandidato $\mathfrak{i}$ Ministro Pirmininko postą, užfiksuotas 2006 m. ankstyvą vasarą (Seimas nepritarè Prezidento Valdo Adamkaus teiktai Zigmanto Balčyčio (LSDP) kandidatūrai ị Ministro Pirmininko postą). Svarbu pabrèžti, kad Lietuvos politineje praktikoje Seimas visada patvirtindavo naujai suformuotos vyriausybès programą.

Formuojant vyriausybes paprastai sudaroma derybų grupè, apimanti partijų, pretenduojančių ì valdžią, atstovus (lyderius), kuri derina tiek vyriausybès programos tekstą, tiek asmenų, užimsiančių ministrų, viceministrų ir pan. valdžios postus, tiek (kartais) darbo koalicijoje vidaus taisykles (koalicinę sutartị). Derybų grupès nariai 
dažniausiai būna koaliciją formuojančių partijų lyderiai, patyrę ir iškilūs tų partijų atstovai Seime. Tačiau kartais svarbūs koalicinių derybų grupès nariai turi ne Seimo, o Europos Parlamento nario mandatą (pvz., Rolandas Paksas iš TTP ir Valdemaras Tomaševskis iš LLRA $2012 \mathrm{~m}$.$) .$

Lietuvoje koalicinių vyriausybių at(si)statydinimo priežastys yra kelios, bet dažniausiai jos atsistatydina dèl eilinių parlamento rinkimų ar kitų priežasčių: Konstitucijoje nurodomos pareigos (101 str.) grąžinti savo igaliojimus, kai išrenkamas naujas Prezidentas (žr. 3 lentelę). Per 1992-2013 m. laikotarpi taip nutiko pusei (6 iš 12) vyriausybès kabinetų. Antroji vyriausybès darbo baigties priežastis yra koalicijos partnerių nesutarimai dèl viešosios politikos projektų, iniciatyvų ir / arba sprendimų. Koalicijos partijų-partnerių tarpusavio konfliktai arba nesutarimai vienos partijos viduje keletą kartų Lietuvoje taip pat lèmé vyriausybès griūtị. Svarbu akcentuoti, kad iki šiol Lietuvoje nė viena vyriausybé neatsistatydino dẻl pirmalaikių Seimo rinkimų ar parlamento opozicijos išreikšto nepasitikejjimo. Pakitusi viešoji nuomonė ar sąmoningas koalicijos išplètimas, įtraukiant papildomas Seime atstovaujamas partijas, taip pat niekada netapo vyriausybės atsistatydinimo priežastimi.

Taigi svarbiausia diskrečioji, ne rutininè (dèl naujų Seimo ar Prezidento rinkimų), priežastis, kodèl Lietuvoje žlunga vyriausybès, yra vidiniai koalicijos partijų-partnerių nesutarimai. Taip atsitiko kas šeštam vyriausybès kabinetui. Tokia tendencija atskleidžia bendrą šalies politinių partijų programinị ir organizacinị nebrandumą bei jų priklausomybę nuo lyderio valios (užgaidų). Šią jžzvalgą sustiprina ir pastebejjimas, kad Lietuvoje dažniausiai formuojami pertekliniai vyriausybès kabinetai, galintys amortizuoti neigiamas politinių partijų nebrandumo pasekmes.

Koalicijos partijų tarpusavio konfliktai ir vienos iš koalicijos partnerių vidaus nesutarimai yra glaudžiai susiję. Seime parlamentinès partijų frakcijos skilo ir jungèsi visose parlamento sesijose. İdomu tai, 
kad visi analizuojamieji vyriausybės kabinetai, išskyrus (kol kas) dabartini, vadovaujamą Algirdo Butkevičiaus, patyrè „politinio turizmo“ pasekmes - bent viena iš koalicijos partijų netekdavo dalies savo narių, ir tai neigiamai atsiliepdavo kabineto darbui (arba nulemdavo vyriausybės atsistatydinimą). Akivaizdu, kad vidiniai nesutarimai vienoje iš koalicijos partijų-partnerių daro neigiamą ịtaką visai vyriausybei, nes destabilizuoja parlamentinès daugumos santykius.

\section{3 lentele. Lietuvos koalicinių vyriausybių atsistatydinimo prie-} žastys (1996-2012)

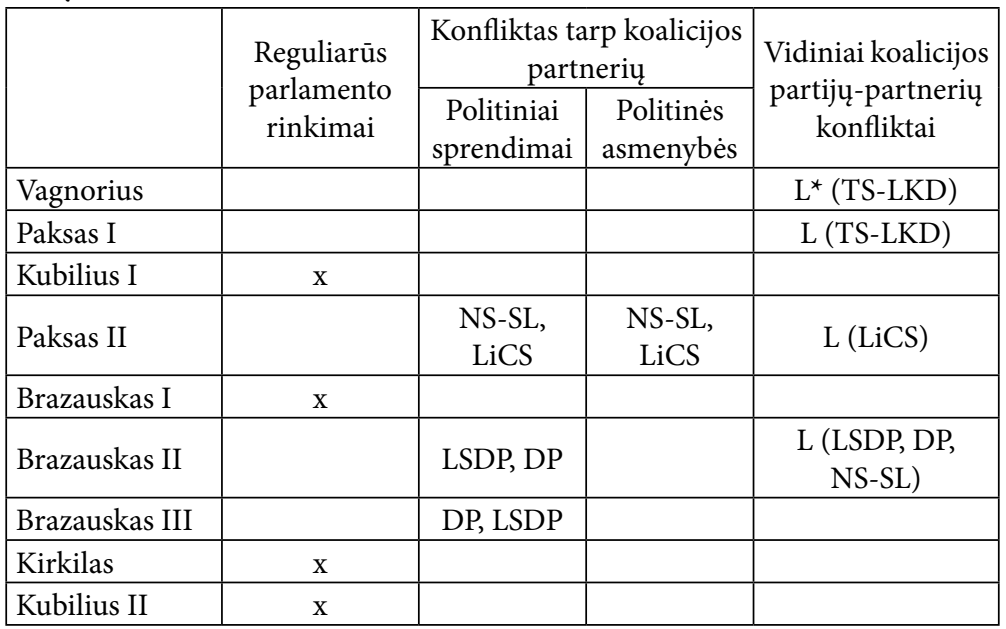

${ }^{*}$ L ženklas reiškia, kad esminis konfliktas, vedęs prie vyriausybės žlugimo, buvo sutelktas vienos ar keleto koalicijos partijų-partnerių lyderių lygmenyje.

Pateikiama keletas pastabų dèl Ministro Pirmininko ir Prezidento galių Lietuvoje. Pagal Lietuvos Respublikos Vyriausybės ịstatymą ir issigalejusias veiklos praktikas Ministras Pirmininkas yra primus inter pares (pirmas tarp lygių) ir jis negali priimti sprendimų, nepasitaręs su visu ministrų kabinetu. Sprendimai vyriausybejje dažniausiai 
priimami visais balsais (Ministras Pirmininkas reziumuoja kabineto diskusijas ir paskelbia bendrą nuomonę). Paprastai Ministras Pirmininkas skiria ir atleidžia ministrus (per formalų teikimą Respublikos Prezidentui). Ministras Pirmininkas neturi igaliojimų keisti ministerijų skaičių, apibrèžti jų igaliojimus ir jurisdikcijas, ši teise priklauso Seimui (t. y. vyriausybès struktūros pakeitimams reikalingas parlamento sutikimas). Premjeras kontroliuoja vyriausybès kabineto darbotvarkę, inicijuoja ir pirmininkauja susirinkimams, taip pat turi teisę koordinuoti ministrų veiklą, bet negali tiesiogiai kištis ị ministerijų jurisdikciją. Taigi, nors Ministras Pirmininkas, akivaizdu, yra iš kokios nors partijos (paprastai didžiausios Seime), premjero poste jis gali ir turi elgtis kaip „konfederatorius“, peržengiantis savo partijos interesus ir atsižvelgiantis ị koalicijos partnerių iniciatyvas, lūkesčius ir ambicijas. Santykinai stipri Prezidento pozicija Lietuvoje matoma analizuojant koalicinių vyriausybių formavimo, valdymo ir atsistatydinimo etapus: po Seimo ir Prezidento rinkimų vyriausybẻ grąžina savo igaliojimus Prezidentui. Prezidentas Seimo pritarimu skiria Ministrą Pirmininką ir naujojo premjero siūlomus ministrus. Prezidento institucija, kuri šalyje yra laikoma patikimiausiu politinès valdžios dariniu, gali stipriai lemti ne tik vyriausybès formavimo procesą, bet ir jos darbo prioritetus bei stilių.

Struktūrinių-institucinių Lietuvos vyriausybių apžvalgos pabaigoje svarbu akcentuoti ir tai, kad Lietuvos Respublikos Konstitucija pabrèžia „fizinès“ vyriausybès sudèties pastovumo ir tęstinumo svarbą: pasikeitus daugiau nei pusei vyriausybès ministrų, Seimas turètų iš naujo tvirtinti vyriausybę (101 str.). Tokia institucinè taisyklè sustiprina politinių asmenybių vaidmenị ministerijose, o interpeliacija ministrams tampa rizikos veiksniu koalicinių vyriausybių ilgaamžiškumui. Beje, Lietuvoje politinès partijos nèra teisiškai ịtvirtintos kaip esminė vyriausybès sudedamoji dalis. Šis trūkumas leidžia (ir skatina) ministrais skirti santykinai daug nepartinių asmenybių. 


\section{Hipotezès}

Remiantis įžvalgomis iš lyginamosios politologijos koalicinių vyriausybių studijų, struktūriniais-instituciniais Lietuvos koalicinių vyriausybių duomenimis ir Lietuvos žiniasklaidos, informuojančios apie koalicinių vyriausybių darbą, visateksčiu archyvu, pateikiamos trys empiriškai tikrintinos tyrimo hipotezès. Nors hipotezių lūkesčiai yra grịsti koalicijų teorijos logika, jų objektas yra ne koalicinių vyriausybių ar jas sudarančių partijų veikla, bet žiniasklaidos - straipsnių autorių ir leidinių redaktorių - sprendimai pasirinkti vieną ar kitą tos veiklos aspektą. Dèl to hipotezės ir jas verifikuojančios duomenų analizès nèra susijusios su vyriausybių ar partijų oficialia komunikacija ar kitokiu bendravimu su žiniasklaida. Straipsnio autoriai daro prielaidą, kad nevaržoma demokratinès valstybès žiniasklaida disponuoja informacijos šaltiniais, nesusijusiais su oficialiąja partijų ir vyriausybių komunikacija, ir dèl to gali, nepriklausomai nuo tokios komunikacijos, spręsti, kuriuos vyriausybių veiklos aspektus akcentuoti apžvalginiuose straipsniuose.

Svarbi techninè pastaba: atliekant šị empirinị tyrimą žiniasklaidos pranešimai koduoti pagal tai, ar jų antrašte yra partinė, ar ne, ir ar pats straipsnis partinis, ar ne. Partiniais laikomi pranešimai, kurių antraštėse ar straipsnių tekstuose vartojamas žodis „partija“ ir jo vediniai, taip pat pranešimai, kuriuose minimi atskirų Lietuvoje veikiančių (veikusių) partijų pavadinimai, jų vediniai ar trumpiniai (libdemai, socialdemokratai, konservatoriai, LLRA ir pan.) bei atskirais, reikšmingais atvejais vartojamos sąvokos „kairieji“, „dešinieji“, „centristai“. Koduojant nèra išskiriama, kas ir kaip sakoma apie partijas, t. y. ar pateikiama teigiama, neigiama ar neutrali informacija apie vieną ar kitą partiją. Taigi šiame žiniasklaidos tyrime reikšmingu laikomas pats „partijos“, kaip tekstą ir analizę struktūruojančios sąvokos, vartojimas. 
Visų pirma tikimasi, kad egzistuoja ryšys tarp koalicinės vyriausybès tipo (mažumos, minimalios persvaros, perteklinės) ir politinių partijų paminejjimų dažnio žiniasklaidoje. Postuluojama, kad kuo mažesnę paramą vyriausybe turi parlamente, tuo labiau jos darbą struktūruoja, kontroliuoja, veikia partijos. Be abejo, partijos, darančios įtaką mažumos vyriausybių veiklai, dažnai būna nekabinetinès (t. y. neturi postų vyriausybėje). Šiame straipsnyje daroma prielaida, kad apžvelgdami ar komentuodami tokių (opozicinių) partijų poveiki mažumos koalicijoms, straipsnių autoriai neišvengia ir valdančiųjų partijų paminejjimo. Tad šis tyrimas atspindi visą koalicijų veiklą komentuojančios žiniasklaidos akiratị. Remiantis šiomis prielaidomis, pranešimuose, informuojančiuose apie mažumos vyriausybès darbą, partijos ir jų tarpusavio sąveika turètų būti minimos dažniau.

Antra, teigiama, kad partijų reikšmė didžiausia vyriausybės formavimo, sudarymo, koalicijos derybų periodu. Šią prielaidą stiprina tai, kad per dirbančios vyriausybès krizę paprastai koalicinès valdysenos šalyse iškyla (ir žiniasklaidoje būna paviešintos) naujos vyriausybès formavimo iniciatyvų. Tad kai kuriais atvejais dėmesys vyriausybès formavimui (t. y. tada, kai nauja vyriausybè atsiranda ne po eilinių parlamento rinkimų) gali būti sustiprintas ir dėmesio vyriausybès krizei, griūčiai, baigčiai, struktūriškai iš esmès sietinai su ịtampos tarp partijų. O vyriausybès darbo, programos igyvendinimo, valdymo laikotarpiu žiniasklaidos pranešimuose partijų dèmuo, tikètina, neturètų būti toks stiprus, nes žiniasklaida turètų daugiau koncentruotis ị ịvairias viešosios politikos iniciatyvas ir sprendimus, rengiamus ir priimamus vyriausybeje, kaip kolektyviniame vienete.

Trečia, teigtina, kad Lietuvos viešojoje erdveje daugiau partinių aspektų žiniasklaidos pranešimuose galima rasti apie pastaraisiais metais suformuotas koalicines vyriausybes. Ši hipotezė pagrịsta „mokymosi veikiant“ prielaida, t. y., viena vertus, stebint ankstyvo- 
sios dvipartinès sistemos mutaciją ị daugiapartinę sistemą, lydimą didelio reikšmingų parlamentinių partijų skaičiaus (pvz., efektyvių parlamentinių partijų skaičius $1996 \mathrm{~m}$. siekè 3,3, o $2006 \mathrm{~m}$. šis rodiklis buvo 7,6; žr. 2 lentelę), manytina, kad Lietuvoje politinis elitas kaupia politinès konkurencijos patirti ir atitinkamai vis geriau perpranta partinio veikimo koalicinejje vyriausybejje galimybes, o, kita vertus, žiniasklaidos atstovai laikui bejgant irgi mokosi ir, aprašydami koalicijų sudarymo, valdymo ir skilimo niuansus, dažniau ir operatyviau (kaip prognozuoja mūsų pirmosios dvi hipotezès) akcentuoja politinių partijų sąveiką ir sąryšius.

\section{Rezultatai}

Susisteminti žiniasklaidos stebėsenos rezultatai pateikiami diagramose. Aprašomoji statistika, savaime suprantama, negali nustatyti priežastinių ryšių tarp kintamųjų. Dėl to šis tyrimas interpretuotinas kaip „zonduojamasis“ - skirtas patikrinti, ar hipotezèse postuluojami kintamųjų ryšiai galètų egzistuoti, ir ar verta jų ieškoti darant didesnị kiekybinị (pvz., grịstą regresine analize) tyrimą.

Kaip matyti 1 diagramoje, žodis „partija“ arba jo dariniai minimi mažiau negu trečdalyje (29 proc.) straipsnių apie koalicinių vyriausybių darbą pavadinimų. Remiantis straipsnių pavadinimų duomenimis, kaip ir tikètasi, galima teigti, kad partinis aspektas kiek ryškiau atsiskleidžia mažumos vyriausybių atveju (pavadinimą, kuriame viena ar kita forma minimos partijos, turi 33 proc. straipsnių). Atitinkamai, vèlgi pagrindžiant pirmosios hipotezès lūkesčius, perteklines vyriausybes komentuojančių straipsnių antraštèse partijos minimos santykinai rečiausiai (25 proc.). 


\section{1 diagrama. Vyriausybès tipas ir partinès antraštės dažnis}

Vidutinis visu straipsniu ir straipsnių su partine antrašte skaičius per koalicijos valdymo metus pagal kabineto tipa

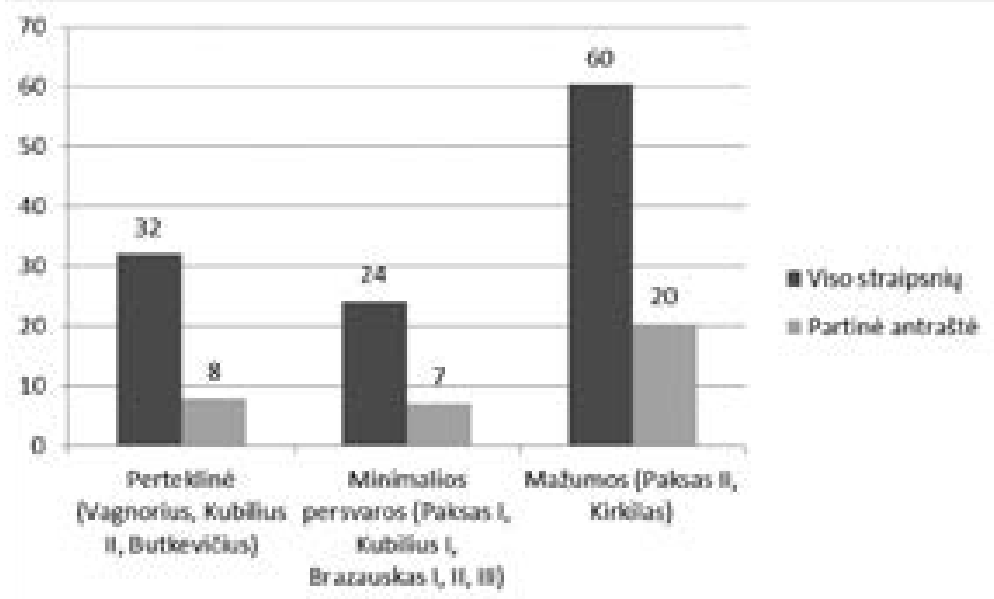

Vis dèlto, kadangi stebejimų variacija nedidelè, o laiko trukmès požiūriu mažumos vyriausybès Lietuvoje yra veikusios itin neilgą laikotarpi, tikslesnei interpretacijai verta pasitelkti nuoseklią (chronologinę ir vardinę) koalicinių vyriausybių ir jų atspindžių žiniasklaidoje analizę. Tokia analizė leistų svariau pagrịsti pradinę ìžvalgą, kad mažumos vyriausybės per se žiniasklaidos tekstuose pritraukia daugiau partinių akcentų pavadinimuose negu kitų tipų vyriausybės. Tačiau turimi empiriniai duomenys (žr. 2 diagramą) neleidžia šios prielaidos patvirtinti. Mažumos vyriausybė, kuriai vadovavo Rolandas Paksas, iš tiesų reikšmingai dažniau negu kitos vyriausybès pritraukdavo partines antraštes (40 proc. versus 29 proc.). Tačiau partinès antraštės nebūdingos mažumos vyriausybei, kuriai vadovavo Gediminas Kirkilas. Kita vertus, minimalios persvaros vyriausybę, kuriai vadovavo Ministras Pirmininkas R. Paksas, aprašančių straipsnių antraštès taip pat labiau pasižymèjo partiniais akcentas negu kitų politi- 
kų (A. Kubiliaus ar Algirdo Mykolo Brazausko) suformuotos minimalios persvaros vyriausybès. Tad čia dera suklusti dèl Rolando Pakso, kaip politinio lyderio, veiklos, kuri galejjo paskatinti Lietuvos žiniasklaidos ir visuomenès dèmesị daugiapartiškumui.

\section{2 diagrama. Vyriausybių seka pagal Ministrą Pirmininką ir partinès antraštès dažnis}

Vidutinis visu straipsnių ir straipsnių su partine antrašte skaičius per koalicijos valdymo metus pagal kabineta

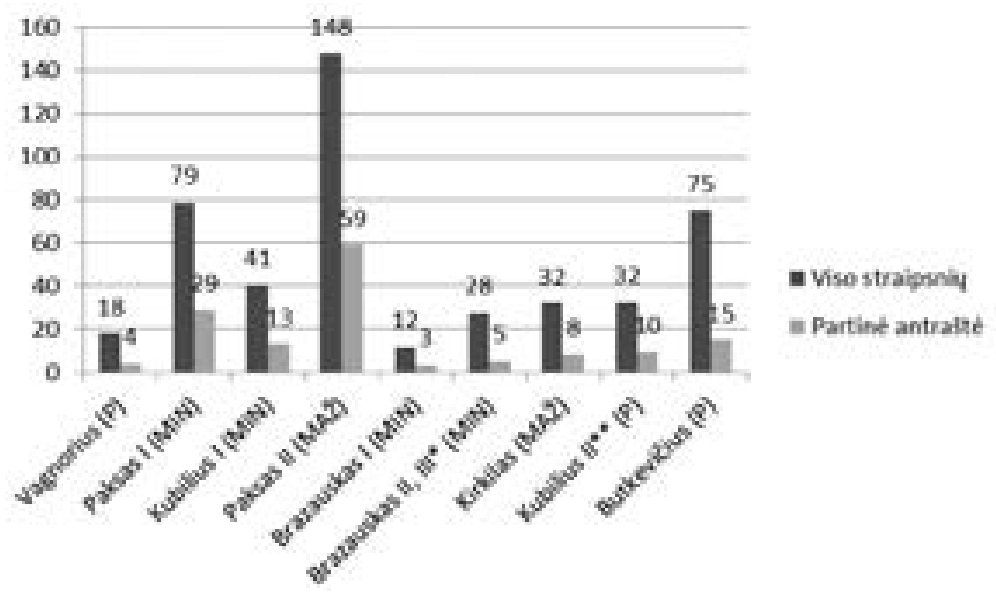

* Brazauskas II, III vyriausybès, išskirtos dèl skirtingos partijų sudèties, čia analizuojamos kartu.

** Šios mažumos vyriausybès atveju 5 straipsniai iš 19 pavadinimuose nemini „partijų“ ar šio žodžio darinių, bet kitoms vyriausybėms nebūdingai dažnai pažymi takoskyrą tarp „kairiųjų“ ir „dešiniųjų“, pvz.: „Vèl susirieję kairieji ir dešinieji bet kuria kaina siekia stiprinti savo stovyklas“, „Valdyti šalį pasiryžę ir kairieji, ir dešinieji turès ieškoti bendros kalbos“, „Kol šalies lyderiai tariasi, kairieji nesnaudžia“, „Jejgas prieš VSD vadovą telkiantys dešinieji grasina premjerui“.

Akivaizdu, kad gilinantis ị žiniasklaidos pranešimus apie politinius ivvykius ir šalies vyriausybès veiklą negalima apsiriboti vien straipsnių 
antraščių analize. Nors negalima atmesti, kad didžiausią informacinị krūvị iš tiesų turi žiniasklaidos pranešimo antraštè, tačiau pilietinè ir kokybiška žiniasklaida neišvengiamai praplečia, patikslina esmini pranešimą pačiame straipsnio tekste. Pakartotinai žiniasklaidos archyve peržvelgus relevantiškus straipsnius, pastebèta, kad straipsnių tekstuose partinis aspektas iš tiesų išryškèja daug labiau nei straipsnių pavadinimuose. Kaip matyti 3 diagramoje, partijos vienaip ar kitaip minimos 79 proc. analizuotų publikacijų, kuriose aptariamas koalicinių vyriausybių darbas Lietuvoje. Šiuo atveju mažumos vyriausybės pritraukia išskirtinai daugiau partinių akcentų, o minimalios persvaros vyriausybės gauna ne tik mažiausiai partinių tekstų, bet ir mažiausiai žiniasklaidos pranešimų bendrai paèmus.

\section{3 diagrama. Vyriausybès tipas ir partinių tekstų dažnis}

Vidutinis visu straipsnių ir straipsnių su partiniu tekstu skaičius per koalicijos valdymo metus pagal kabineto tipa

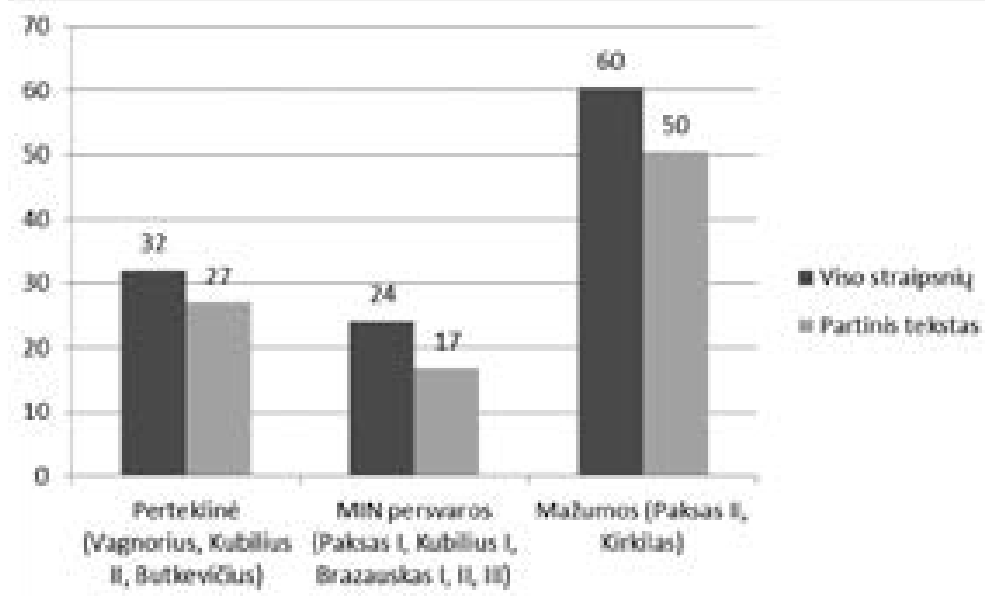

Peržvelgus ministrų kabinetus pagal jiems vadovavusius politikus (žr. 4 diagrama), svarbu akcentuoti, kad, išskyrus dabartinę Algirdo Butke- 
vičiaus vadovaujamą perteklinę vyriausybę, dažniausiai straipsnių tekstuose partijos buvo minimos R. Pakso vadovautos mažumos vyriausybės atveju (86 proc.). Tai dar sykị atkreipia dėmesị i politiko R. Pakso išskirtinumą Lietuvos partijų dinamikos ir partinès sistemos pokyčių kontekste.

\section{4 diagrama. Vyriausybių seka pagal Ministrą Pirmininką ir par- tinio teksto dažnis}

Vidutinis visu straipsniu ir straipsniu su partiniu tekstu skaičius per koalicijos valdymo metus pagal kabineta

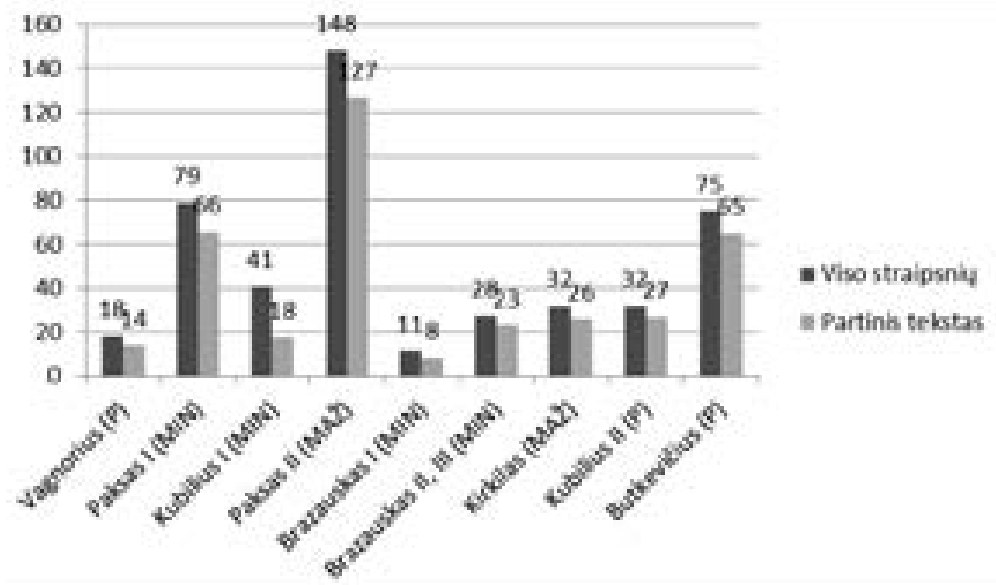

Straipsnių antraščių ir tekstų analizès rezultatai leidžia teigti, kad partijos kur kas dažniau minimos straipsnių tekstuose, o ne jų antraštèse. Nors partinis aspektas Lietuvos žiniasklaidos tekstuose akcentuojamas kur kas dažniau nei antraštėse, tyrimo rezultatai rodo, kad penktadalyje publikacijų partijos iš viso neminimos (tai vargiai įmanoma bet kokiame lyginamosios politikos aspektu rašomame tekste apie koalicines vyriausybes).

Tikrinant antrąją hipotezę, suponuojančią, kad būtent vyriausybės formavimo laikotarpiu partijų reikšmè yra pati didžiausia, pastebima, kad vis 
dèlto tiek straipsnių antraštėse, tiek straipsnių tekstuose partijos dažniau figūruoja vyriausybių valdymo, o ne formavimo periodu. Šiek tiek daugiau nei pusè visų partinių antraščių ir partinių tekstų buvo pateikta koalicinių vyriausybės valdymo, t. y. „normalaus darbo“, periodu (žr. 5 diagramą).

Techninio paaiškinimo, akcentuojančio, kad Lietuvoje žiniasklaidos archyve „natūraliai“ galèjo atsirasti daugiau dèmesio vyriausybès normalaus darbo laikotarpiui, kuris summa summarum fiziškai buvo ilgesnis negu vyriausybių sudarymo arba atsistatydinimo periodai, nepakanka vien dèl to, kad, kaip minèta, šioje žiniasklaidos stebėsenoje buvo vadovaujamasi konfliktus, ịtampą vyriausybejje atspindinčių tekstų (antraščių) paieška pagal išskirtus reikšminius žodžius-temas ir nebuvo renkami tekstai, kuriuose būtų paprasčiausiai supažindinama su vyriausybės vykdoma viešaja politika. Tad atmestina mintis, kad Lietuvos žiniasklaida (ir politikai) brandžiai ir sèkmingai peržengé „holivudinį“ domėjimosi koalicinėmis vyriausybèmis slenkstị, daugiausia dėmesio skiriantị vyriausybès formavimui (palyginimui - tipiškas Holivudo filmas daugiausia koncentruojasi ị flirtą, sužadètuves, meilès romaną iki vestuvių, o ne į povestuvinio gyvenimo kartu rutiną $^{28}$ ). Svarbesnis paaiškinimas toks, kad, nors formaliai Lietuvoje koalicinès vyriausybès ir būna suformuotos, jų „formavimas“ tęsiasi ir joms dirbant, nes visoms Lietuvos vyriausybèms (parlamentinei daugumai) būdingas nepastovumas, „politinis turizmas“, politinių partijų partnerių vidaus konfliktai, skilimas ir panašūs vyriausybès formavimą iki pat atsistatydinimo pratęsiantys rūpesčiai (žr. 2 lentelę, stulpelius „Kabineto stiprumas vyriausybės darbo pradžioje“ ir „Kabineto stiprumas vyriausybès darbo pabaigoje“). Pavyzdžiui, antroji premjero Andriaus Kubiliaus vadovauta vyriausybė techniniu, oficialiu požiūriu buvo suformuota $2008 \mathrm{~m}$. gruodžio $9 \mathrm{~d}$., bet praktiškai dèl TPP ir pačios TS-LKD vidaus įtampos „formavosi“ per visą vyriausybès gyvavimo laikotarpị ir darbą baigè toli gražu ne kaip perteklinė vyriausybė. Panašias išlygas galima pateikti ir apie kitas „permanentišką formavimąsi“ išgyvenusias vyriausybes (Paksas II,

${ }^{28}$ Coalition governments in Western Europe. Edited by W.C. Muller, K. Strom New York: Oxford University Press, 2006, p. 13, 16-25. 
Brazauskas II, III ir pan.). Verta atkreipti dèmesį, kad žiniasklaidoje partinis aspektas vyriausybių atsistatydinimo laikotarpiu yra ypač retas: tik kas dešimta antraštė šia tema pasižymi partiniu aspektu. Tai dèsninga ir suprantama, nes, pirma, dauguma vyriausybių Lietuvoje savo darbą baigia dèl eilinių Seimo rinkimų (atitinkamai nèra didelio ažiotažo dèl vyriausybès darbo baigties); antra, at(si)statydinant konkrečiai vyriausybei paraleliai jau vyksta naujos vyriausybès formavimas, ir, trečia, kaip atskleidžiama 3 lentelejje, absoliuti dauguma „partinių“ konfliktų, kurie lèmè vyriausybès žlugimą, remiantis Lietuvos koalicinės valdysenos patirtimi, daug stipriau siejasi su politiniais (partijų) lyderiais negu su platesniais partiniais nesutarimais, ịtraukiančiais daug partijos narių ir besiremiančiais nuosekliomis partijų programinėmis ideologinėmis pozicijomis ir / ar partijų elektorato interesų gynimu.

5 diagrama. Partijų minējimo dažnis straipsnių antraštėse ir tekstuose skirtingais vyriausybės gyvavimo periodais

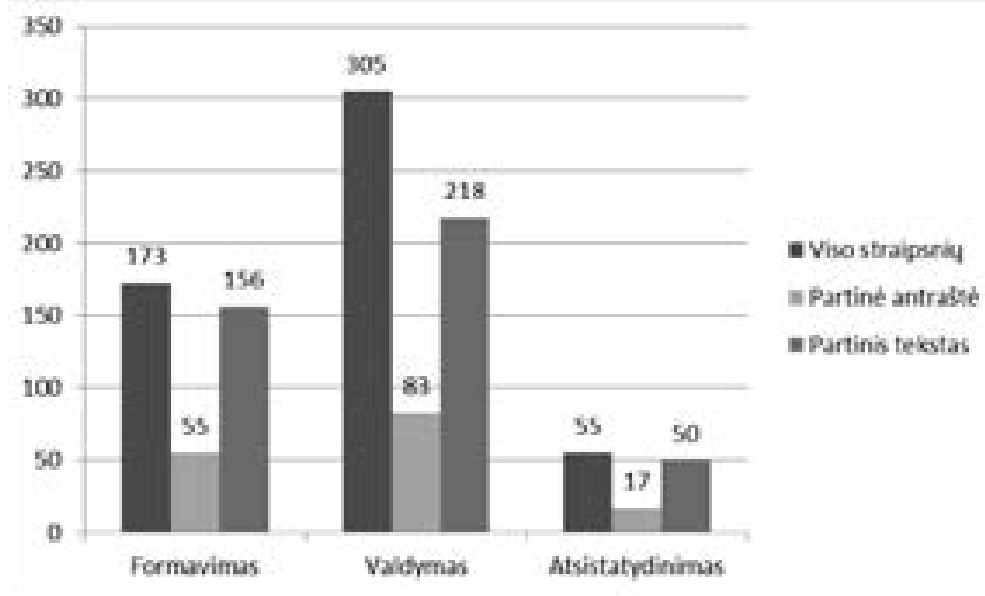

Svarbu pastebeti, kad partinis aspektas vyriausybių formavimo laikotarpiu (tiek antraštèse, tiek straipsnių tekstuose) irgi domi- 
navo mažumos vyriausybių atveju. Pavyzdžiui, mažumos vyriausybių sudarymas paminètas daugiau negu trečdalyje (21 iš visų fiksuotų 55) partinių antraščių ir beveik pusèje partinių tekstų (64 iš 156).

Tyrimo duomenimis, 20 proc. apžvalginių straipsnių, kuriuose buvo aprašomas koalicinių vyriausybių Lietuvoje sudarymas ir darbas, nè viena politinè partija neminima ne tik antraštejje, bet ir visame tekste (žr. 5 diagramą).

Trečioji hipotezė teigia, kad politikai ir žiniasklaidos atstovai laikui bėgant mokosi ir vis geriau perpranta partijų struktūruojamą koalicinès vyriausybės darbo „virtuvę“, todèl partijoms skiria vis daugiau dèmesio. Šiai hipotezei patikrinti visas turimas žiniasklaidos archyvas buvo suskirstytas i 3 kalendorinių metų atkarpas: kiekviename periode būta ir Seimo rinkimų, vyriausybès formavimo, ir atsistatydinimo patirties (išskyrus dabartinị, nuo 2012 m.). Tačiau chronologinis tyrimo rezultatų išdèstymas (žr. 6 diagramq) atskleide, kad partinis aspektas žiniasklaidoje, t. y. apžvalginių straipsnių antraštėse ir tekstuose, per stebimus penkiolika metų neišaugo, o santykis tarp partinių akcentų ir nepartinių straipsnių antraščių išliko gana pastovus (vienas su trimis, $1: 3$ ), neprogresavo ir partinių akcentų žiniasklaidos tekstuose dažnis (apie 80 proc.). 2000-2003 m. laikotarpiu pastebètas partinių antraščių „šuoliukas“ (iki 42 proc.) buvo savotiškai neutralizuotas partinius aspektus mažiau negu paprastai aprašančių straipsnių (72 proc.). Pastaruoju metu (2012) stebima atvirkštinè tendencija - straipsnių pavadinimuose partiniai akcentai blankesni negu „norma“ (21 proc. versus 29 proc.), bet straipsnių, kuriuose reikšmingai figūruoja partijos, atsiranda daugiau (88 proc.). Vis dèlto žiniasklaidos tyrèjai pabrèžia būtent antraštès, o ne teksto reikšmę komunikacijoje. 
6 diagrama. Chronologinè straipsnių seka: partiniai aspektai tekstuose ir jų antraštėse

Vidutinis visu straipsniu, straipsniu su partine antrašte ir straipsniu su partiniu tekstu skaičius pagal laikotarpi ir tiesines tendencijos

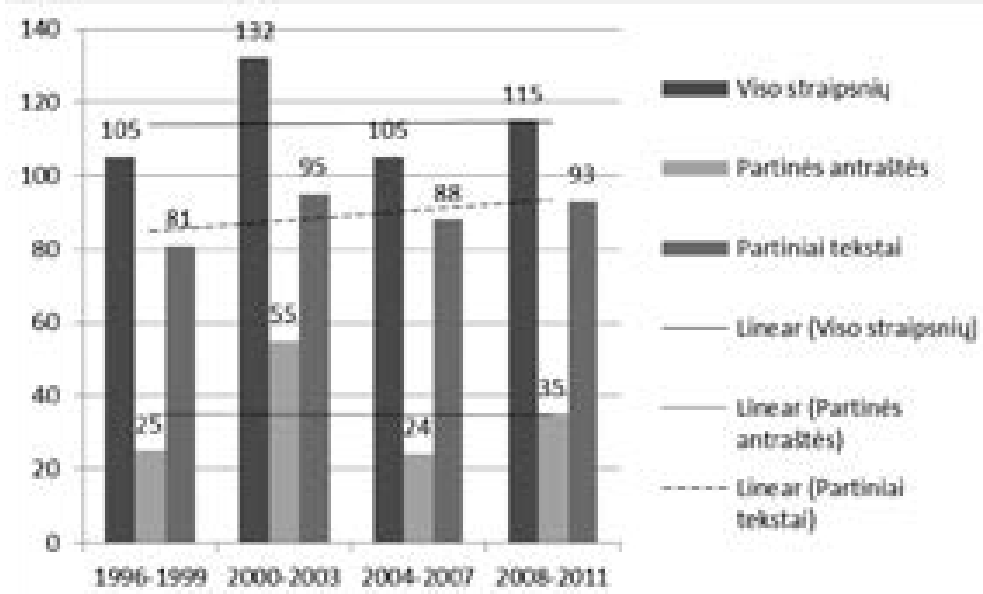

* Dabartinis straipsnių archyvas apima tekstus iki 2013 m. rugpjūčio mèn. Šioje diagramoje nevaizduojami rezultatai iš „trumpojo“, 2012-2013 m., laikotarpio. Tolimesnis palyginimas bus galimas sukaupus galutinị analogišką 4 metų laikotarpio (2012-2015) archyvą.

\section{Išvados, apibendrinimai, gairès tolimesniems tyrimams}

Lietuvos žiniasklaidos tyrimas atskleidè, kad tik kai kurios prielaidos, darytos remiantis reikšmingu partijų vaidmeniu koalicinëje valdysenoje, pasitvirtino. Apskritai menkas žiniasklaidos dèmesys politinems partijoms, kaip institucijai, suponuoja, kad politinis gyvenimas Lietuvoje yra gana personalizuotas, o Lietuvos žiniasklaida nèra pakankamai pasirengusi vykdyti pilietinio forumo, kokybiško ir brandaus politinio „komunikatoriaus" vaidmeni. 
Vis dèlto iš esmès pasitvirtino esminis politologinis lūkestis, siejamas su koalicinių vyriausybių tipologija: žiniasklaidos pateikiamame informacijos turinyje, susijusiame su Lietuvos koalicinemis vyriausybėmis, politinèms partijoms skiriama santykinai daugiau dèmesio mažumos vyriausybių atveju, t. y. tuomet, kai valdžia turi derinti praktiškai visų parlamente atstovaujamų partijų interesus (ir tų partijų lyderių igeidžius ar kaprizus). Désninga, kad perteklinių vyriausybių atveju $\mathfrak{i}$ žiniasklaidos radarą partijos, kaip svarbūs koalicinès valdysenos elementai, papuola žymiai rečiau. Taigi, pirmoji hipotezè, žiniasklaidos dėmesị politinėms partijoms koalicinèse vyriausybėse siejanti su parlamentinès daugumos (ne)buvimu, Lietuvos atvejo studijoje nebuvo paneigta.

Antroji hipotezè, postuluojanti, kad politinès partijos reikšmingesnès koalicinių vyriausybių sudarymo (formavimo) periodu, nepasitvirtino. Žiniasklaidos tekstuose apie Lietuvos koalicines vyriausybes politinès partijos, kaip svarbus kolektyvinis veikejjas, išryškejja ne vyriausybių sudarymo, o vyriausybių darbo (išsilaikymo valdžioje) periodu. Tai sietina su parlamentinès daugumos nepastovumu (Seimo narių „politiniu turizmu“, parlamentinių partijų skilimu, jungimusi ir pan.), didinančiu koalicinių vyriausybių rizikos aplinką, kurioje vyriausybių darbas turi būti palaikomas nuolatinių partijų lyderių pastangų išlaikyti vyriausybę ir joje pasiekti konsensuso.

Trečioji tyrimo hipotezė, kad Lietuvoje politikai ir žiniasklaidos atstovai laikui bejgant mokosi ir atitinkamai kokybiškiau, t. y. daugiau dèmesio skirdami politinèms partijoms, valdo ir / ar perteikia su koalicinių vyriausybių veikla susijusias naujienas, nepasitvirtino. Chronologinè straipsnių seka neatskleide aiškios mokymosi tendencijos - partinių aspektų straipsnių antraštėse ir pačiuose tekstuose apie pastaraisiais metais suformuotas koalicines vyriausybes daugiau neatsirado, nors tam tikras „partinis“ pakilimas žiniasklaidoje buvo 2000-2003 m., būtent tada, kai Lietuvoje vyko svarbi partinė politinio gyvenimo fragmentacija. 
Šiame tyrime žiniasklaidos turinys laikomas labai svarbiu informacijos, pateikiamos vartotojams ir veikiančios aptariamų valdžios veikejjų elgseną, filtru. Straipsnyje akcentuotos žiniasklaidos, kaip pilietinio forumo, funkcijos. Tyrimo metu netiesiogiai išryškejjo tam tikri dabartinès Lietuvos žiniasklaidos (nacionalinių dienraščių ir informacinių portalų) trūkumai kokybiškai ir korektiškai išpildyti savo, kaip pilietinio švietimo vykdytojo, užduotis. Analizuotuose žiniasklaidos straipsniuose (atrinktuose faktinei informacijai apie Lietuvos koalicines vyriausybes patikrinti ir kokybinèms įžvalgoms daryti) pastebėtas akivaizdus atotrūkis tarp tekstų antraščių (ir iliustracijų), siekiančių patraukti skaitytojo dèmesí, bei straipsnių turinio, kuris yra daug dalykiškesnis ir nuosekliau mini politines partijas bei atkreipia dèmesi $\mathfrak{i}$ jų vaidmenị koalicinių vyriausybių darbe. Šioje vietoje verta paminèti, kad Pippa Norris ${ }^{29}$, priskirdama žiniasklaidai pilietinio forumo funkcijas, taip pat išskiria dar dvi šiuolaikinėms visuomenès informavimo priemonèms būdingas funkcijas: mobilizuojančio agento ir sarginio šuns. Šiame tyrime netiesiogiai atskleista, kad Lietuvos žiniasklaida orientuojasi $\mathfrak{i}$ mobilizuojančio agento funkcijų atlikimą - siekiama naujienų vartotojų įsitraukimo (pvz., komentarų rašymo dažnis), kai pilietinis aktyvizmas nebūtinai glaudžiai susijęs su nuosekliu domèjimusi politiniu šalies gyvenimu ir aiškiomis pilietinėmis pozicijomis. Kita vertus, Lietuvos žiniasklaida intensyviai veikia ir kaip sarginis šuo, nes aprašo galimą piktnaudžiavimą valdžia, viešus skandalus, valdžios nesèkmes. Žiniasklaidai, kaip sarginiam šuniui, nèra svarbi koalicinių vyriausybių formavimo ir darbo „kasdienè virtuvë“ (kurioje, tikètina, politinių partijų vaidmens ir vietos neatpažinti neįmanoma). Sarginiam šuniui svarbiau skandalai, problemos, asmenybių veikla. Šiuo požiūriu svarbu pastebėti, kad žiniasklaida žymiai daugiau "partinio“ dèmesio skyrè, pvz., R. Pakso, o ne G. Kirkilo vadovautoms vyriausybei, nors abi vyriausybės politologinèse koalicinès valdysenos studijo-

${ }^{29}$ Norris, P. A virtuous circle: political communications in postindustrial societies. Cambridge: Cambridge University Press, 2000. 
se yra gana panašios (mažumos vyriausybès). Žiniasklaidos koalicinès valdysenos stebėsena netiesiogiai parodè, kad Lietuvoje politinès partijos dažnai nèra taip gerai matomos, kaip politiniai lyderiai ar asmenys, užimantys vieną ar kitą svarbų postą. Turinio požiūriu žiniasklaidos pranešimuose dominuoja neigiamos žinios: mažai dėmesio skiriama koalicijos darbo turiniui, vyriausybinès galios telkimui, stiprejimui ir sèkmingai veiklai bei laimejjimams; dažniausiai rašoma apie koalicinių vyriausybių darbo sunkumus ir trūkumus, aptariama vieno ar kito ministro at(si)statydinimo tikimybè ar galima koalicijos griūtis.

Galimos ir kitos šios žiniasklaidos stebėsenos rezultatų tyrimo kryptys. Pavyzdžiui, galima gilinis ị tai, kaip profiliuojami skirtingų dienraščių ir interneto naujienų portalų pranešimai. Taip pat ilga tęstinẻ Lietuvos žiniasklaidos stebėsena (praktiškai ji apima beveik dvidešimties metų laikotarpi) sudaro pagrindą analizuoti, kaip keitèsi Lietuvos dienraščių ir informacinių portalų žurnalistinio darbo kultūra, politinis-pilietinis issitraukimas ir pan.

Straipsnyje vartojamų Lietuvos partijų santrumpų sąrašas:

LCS Lietuvos centro sajunga

LiCS Liberalų ir centro sąjunga

LLS Lietuvos liberalų sąunga

LSDP Lietuvos socialdemokratų partija

MKDS Moderniųjų krikščionių demokratų sąjunga

NS-SL Naujoji sąunga (socialliberalai)

PDP Pilietinès demokratijos partija

TPP Tautos prisikèlimo partija

TS-LKD Tẻvynès sajunga - Lietuvos konservatoriai

VNDS Valstiečių ir Naujosios demokratijos partijų sąunga 


\section{PARTICIPATION OF POLITCAL PARTIES IN COALITION GOVERNMENTS: REFLECTIONS IN THE LITHUANIAN MASS-MEDIA (1996-2013)}

\section{IRMina MATONYTÉ, VinCENTAS VobOLEVIČIUS}

\section{Summary}

Keywords: Lithuania; coalition government party; prime minister; national daily; news website; heading; text.

Political parties play a key role in the functioning of coalition cabinets; therefore it is reasonable to expect the media to pay considerable attention to political parties while covering activities of coalition governments. This interdisciplinary exploration draws on methodologies of Comparative Politics and Media Studies in order to ascertain whether Lithuanian media emphasize political parties as important factors of coalition governance. The article begins by introducing readership trends for daily print newspapers and news websites that have been studied as a part of Lithuanian media monitoring, along with methodology of the project. Next we discuss the importance of political parties in the context of coalition governance in Lithuania, paying particular attention to partisan aspects of coalition formation, maintenance and dissolution. We build on he insights of coalition theory to produce three testable hypotheses about the focus of national print media on political parties acting in Lithuanian coalition cabinets. In the empiri- cal study we analyze data, gathered by monitoring text-based media, encompassing articles related to the functioning of Lithuania's coalition cabinets between 1996 and 2013. The findings show that, consistently with expectations, articles describing and commenting activities of Lithuanian coalition governments dedicated more attention to political parties when writing about minority cabinets; in the meantime, articles concerning the work of minimal winning coalitions placed less emphasis on political parties. On the other hand, contrary to expectations, political parties as collective actors have received most attention during the operation, as opposed to the formative stage of coalition life. Chronological analysis of publications has also led to rejecting a hypothesis that journalists learn over time to pay closer attention to the significant role that political parties play in coalition cabinets. It is also worth noting that Lithuanian media produces significantly fewer partisan aspects in article headlines than in actual texts.

Iteikta 2014 m. spalio $10 \mathrm{~d}$. 